\title{
Microstructure analysis in the creep process of a gas turbine blade of the turbine engine
}

\begin{abstract}
The technical condition of gas turbine blades of the turbine engine has a significant impact on the reliability and life span of the turbine and the entire engine. In order to assess the blades'technical condition, a visual method, with the use of optoelectronic devices, is used. In order to verify this assessment, metallographic tests are conducted.

The paper presents the results of microstructural tests of the turbine rotor blades made of nickel-based monocrystalline super alloys. The aim of these tests was to determine the consequences of impacting high exhaust gas temperature and stresses occurring during operation on the stability of the blade microstructure. The progress level of the blade microstructure changes in the post-operational stage for different sections towards the blade vertical axis and was compared with the blade microstructure on delivery made of the same super alloy. A varied degree of the microstructure degradation for different blade sections was shown. The changes typical of the high-temperature creep process - $\gamma^{\prime}$ phase directional growth (rafting), were observed only for the thinnest walls of the upper section of the turbine blade leaf.
\end{abstract}

Key words: turbine engine, turbine blade, loads, microstructure, rafting

\section{Introduction}

A turbine is a rotor turbomachine converting enthalpy of the work factor, also called the thermodynamic factor, into mechanical work making the rotor rotate. Therefore, the turbine engine overall performance depends on its power and reliability. The turbine efficiency, which varies from $30-45 \%$, decreasing during the operation, substantially depends on the exhaust gas temperature. However, increasing exhaust gas temperature is limited by the material properties of the turbines: their resistance to creeping, microstructure change (overheating), thermal fatigue, high temperature corrosion, etc. $[1,5,14]$.

The most unreliable elements of the gas turbine include the rotor blades [2,9]. During the operation, they are subject to imposed loads: mechanical one as a result of rotation, as well as aerodynamic and heat ones from the work factor airflow. In addition, the chemical aggression of high temperature exhaust gases affects them. Their reliability and life span is a sum of many factors, but the predominant importance plays the material. The high and stable strength properties of super alloys in structural terms constitute the proper microstructure that is not subject to weakening operational changes $[4,14,17,18]$.

The improved turbine materials were obtained thanks to the development of alloys based on nickel and cobalt. These materials can operate at a homological temperature, higher than 0.85 [6]. In addition, in order to increase the mechanical properties, chrome, titanium, molybdenum, vanadium, tungsten, niobium, tantalum, etc. [4, 14] are added.

The further development of heat-resistant materials is super alloys created with methods of directional crystallization and mono crystallization. The super alloys directional crystallization technology allows to increase the blade operating temperature by even more than $1000 \mathrm{~K}$ [3]. However, the elimination of grain boundaries by using the monocrystalline casting improves the super alloy resistance to creeping. Using these manufacturing technologies allowed a fivefold increase of fatigue strength and a tenfold increase of durability at a high temperature, in comparison with the blades produced from polycrystalline super alloys [6].

Moreover, heat-resistant coatings with good thermal conductivity and high structure stability are applied on gas turbine blades operating in extreme temperature conditions. Thermal properties of the coatings mainly depend on the composition of the material and microstructure, i.e. grain size, porosity and impurities [16]. Different types of protective coatings, obtained with many methods are used. Diffusion coatings on aluminium warp and their variations known as modified coatings are the most commonly used [7, 8, 15]. These coatings consist of a priming layer and an insulation layer. The ground material is usually an alloy on the basis of nickel or cobalt. That layer should be characterised by resistance to oxidation and corrosion, low tendency to form brittle transition phases and transfer of micro-deformations from the base to the insulation layer [12]. The insulation layer should be characterised by the very low thermal conductivity, expressed by a temperature coefficient of thermal conductivity and by thermal diffusivity.

A further step aimed at increasing the exhaust gas temperature and decreasing the blades temperature includes their internal cooling with air from behind the engine compressor. This allows to lower the temperature of the blade material in relation to the temperature of the circumfluent exhaust stream by over $600 \mathrm{~K}[2,13]$. Furthermore, better distribution of temperature onto the blades in the turbine work transients is obtained.

Moreover, in order to increase durability, the complex geometric shapes of blades are designed, which unfortunately complicates their technological manufacturing processes. They are shaped in such a way, so as not to create vibration 

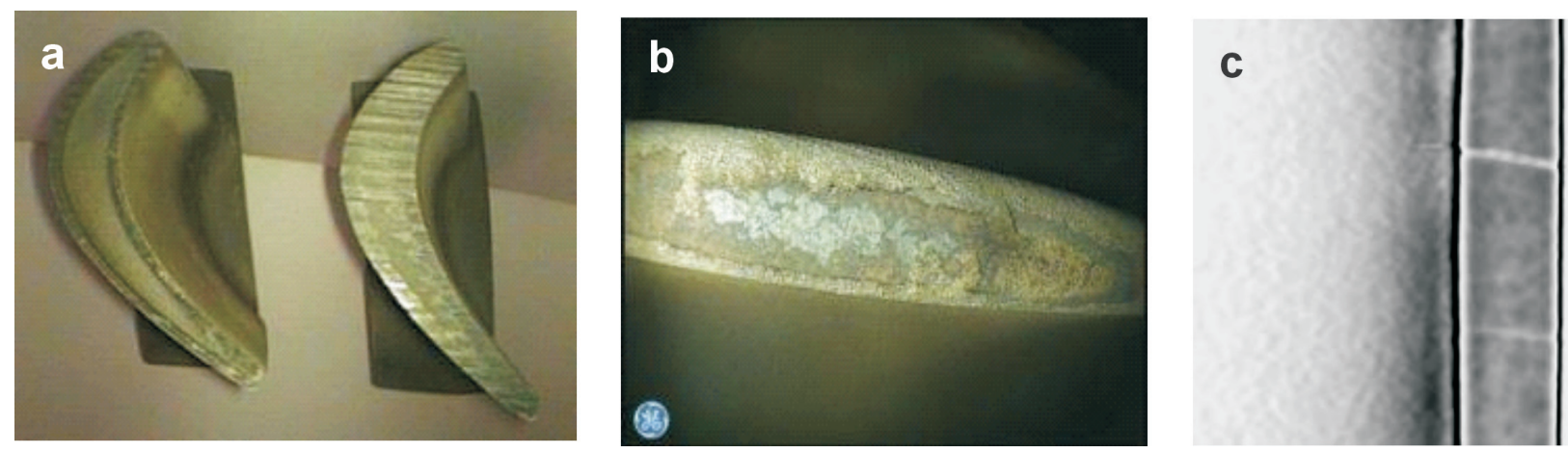

Fig. 1. Example forms of damage to gas turbine blades: a) the turbine blade tip chafing and its wear, b) total burn out of the coating until the leading edge alloy is revealed, c) the turbine blade leaf tomogram with a visible crack inside the leading edge [10]

resonance during interruption of engine work [11]. Plates on the tips (fronts) or near the turbine blade tips, which act as dampers eliminating a dangerous form and frequency of vibrations and increasing tightness in the turbine rotor tip clearance are also applied. The minimum clearance prevents the work factor. On the other hand, it can cause rubbing of the blades fronts against the turbine body (Fig. 1a) due to the blade thermal expansion. It leads to the additional heating of the turbine blade leaf front, the result of which is the increased turbine blade leaf expansion, as well as unfavourable changes of its microstructure, and consequently the need to repair the turbines $[1,4]$.

As it is clear from the above analysis, despite using many endeavours in order to improve the efficiency of the gas turbine operation, its durability and reliability, over the long-term operation process, there are still all kinds of damages to turbine elements, especially their blades (Fig. 1). It is possible to differentiate defects being the results of material and technological faults, derogations from the quality of production and repairs, and operational ones in particular. The important reasons also include improper fuel atomization in the combustion chamber, as well as its diminished physical-chemical properties [3].

\section{Experiment}

Two gas turbine rotor blades of the turbine engine were proposed for microstructural tests. One of them was at the post-operational stage (marked No. 2) and the reference one was newly after delivery (marked No. 1). Metallographic specimens were prepared transversely and longitudinally to the blades axis (respectively: transverse and longitudinal specimens) from the selected gas turbine blades. The preparation of specimens included cutting the blades with a diamond blade with a thickness of $0.8 \mathrm{~mm}$, and then mounting each section in thermoplastic resin, ensuring the electrical conductivity. The preparation of the specimen's layer for microscopic observation included grinding with the use of sandpapers with the grit from 400 to 4000 , and then precise polishing with the use of diamond suspension and polishing discs. The prepared metallographic specimen did not undergo etching in order to avoid etching of individual components of the super alloy microstructure.
Testing with a technique of light microscopy (LM) was made with the use of the Axio IMAGER M1m microscope by the company ZEISS. The microstructure observation with a technique of scanning electron microscopy (SEM) was made with the use of the Merlin Gemini II high resolution electron microscope by ZEISS, equipped with an electron gun with field electron emission (FEG) as well as the characteristic EDX Quantax 800 X-ray detector, and the Brucker company software. In order to conduct the quantitative analysis of images made with the use of the light and scanning electron microscopy, the AnalySIS 3.2 computer software was used.

\section{Research results}

The chemical composition analysis of blades No. 1 and No. 2 was carried out by the means of spectrometry of characteristic X-ray (EDX) with the use of SEM from the leading edge of the transverse specimen. The research was conducted at low magnification (from a large area of the leading edge) in order to average the chemical composition of dendritic and inter-dendritic areas. The analysis results were presented in Table 1. Both blades had a similar chemical composition, and minor differences in the content of the following elements, such as Cr, Ta, W, were shown.

Table 1. Summary of the chemical composition analysis, SEM-EDX for blades No. 1 and No. 2, (\% of weight)

\begin{tabular}{|l|c|c|c|c|c|c|c|c|c|}
\hline Blade & $\mathrm{Al}$ & $\mathrm{Cr}$ & $\mathrm{Co}$ & $\mathrm{Nb}$ & $\mathrm{Mo}$ & $\mathrm{Ta}$ & $\mathrm{W}$ & $\mathrm{Re}$ & $\mathrm{Ni}$ \\
\hline No. 1 & 6.1 & 5.1 & 10.8 & 1.3 & 1.2 & 1.2 & 8.4 & 3.0 & 62.4 \\
\hline No. 2 & 6.3 & 5.5 & 10.6 & 1.4 & 1.3 & 0.5 & 9.1 & 3.0 & 62.0 \\
\hline
\end{tabular}

\subsection{Blade No. 1}

The microstructure of blade No. 1 observed with the use of light microscopy (LM) in the section of the blade locking was presented in Figures $2 \mathrm{a}$ and $\mathrm{b}$. In the microstructure of blade No. 1, the dendritic structure, which was formed in the crystallisation process, Fig. 2a, and characteristic of the monocrystalline castings of the blades crystallized in the axis [001] was observed. The macroscopic examination was conducted within the area of the blade leading edge, and allowed to determine that the average distance of the primary dendrite arms is $348 \pm 29 \mu \mathrm{m}$, however, the average length of the secondary dendrite arms is $173 \pm 28 \mu \mathrm{m}$. 

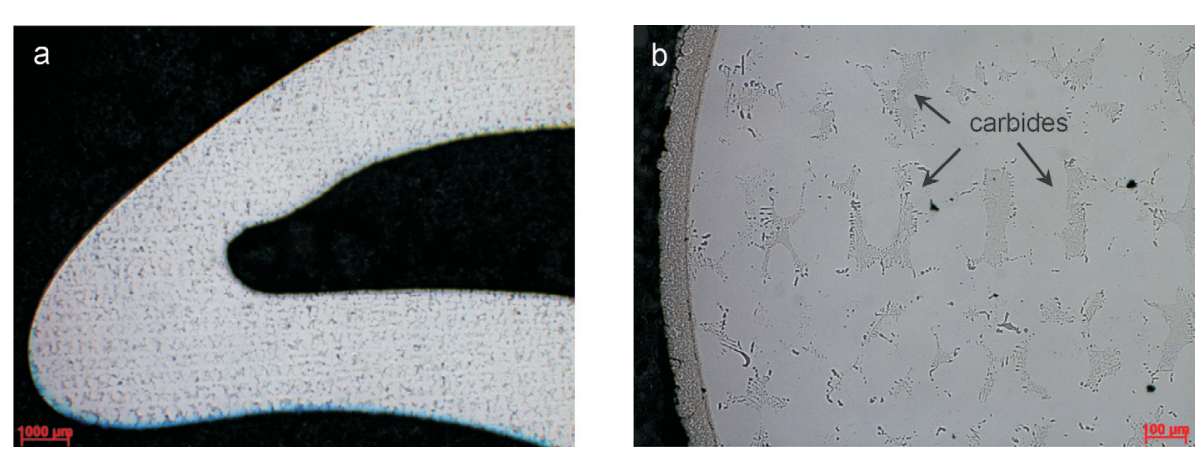

Fig. 2. The microstructure of the blade No. 1: a) cross-section by the blade locking, the dendritic structure, b) carbides particles with the "Chinese-script" morphology, LM blade tip). The dendritic structure formed during the crystallization process was observed, Fig. 4a. Microscopic observations of the blade revealed the deviation from correct orientation of the crystallization direction, Fig. 4b. This blade was partially crystallized at an angle of approx. $90^{\circ}$ in relation to the correct crystallization axis of monocrystalline blades [001]. The macroscopic examination, which was conducted within the area of the blade leading edge at the cross-

Within this microstructure, numerous carbides that have the "Chinese-script" morphology were also observed in the inter-dendritic areas, Fig. 2 b.

The microstructure within the leading edge observed with the use of the scanning electron microscope (SEM) was presented in Figures $3 \mathrm{a}$ and $\mathrm{b}$. Within the dendritic areas, the cuboidal $\gamma^{\prime}$ phase particles separated by the $\gamma$ phase matrix channels were determined, Fig. 3a. In the inter-dendritic areas, the $\gamma-\gamma$ ' eutectic system as well as a large number of carbides of the so-called "Chinese-script" morphology were observed, Fig. 3b. The average size of the $\gamma$ ' phase particles within the dendritic areas was measured and it equalled 0.33 $\pm 0.75 \mu \mathrm{m}^{2}$, however, the $\gamma^{\prime}$ phase surface fraction in these areas was established to be at the level of $66 \%$.

The longitudinal specimen was cut along the blade axis at a distance of about $6 \mathrm{~mm}$ from the leading edge in order to
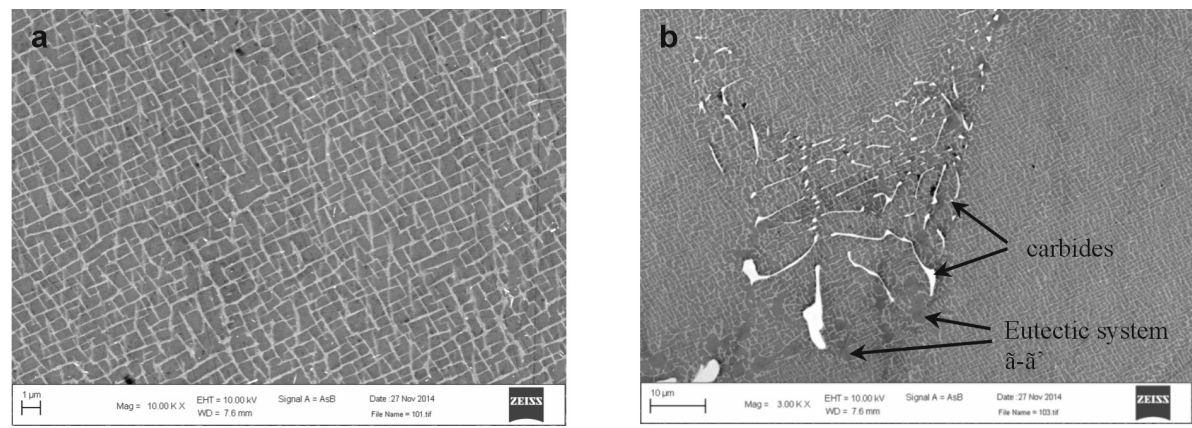

Fig. 3. The microstructure of blade No. 1, cross-section at the locking: a) $\gamma$ ' phase particles separated by $\gamma$ phase matrix channels, b) inter-dendritic area, $\gamma-\gamma^{\prime}$ eutectic system, carbides particles with the "Chinese-script" morphology, SEM the crystallization direction), allowed to determine that the average distance of the primary dendrite arms is $325 \pm 65 \mu \mathrm{m}$, however, the average length of the secondary dendrite arms is $138 \pm 55 \mu \mathrm{m}$.

Within the cross-section dendritic areas at the locking, very small ordered cuboidal $\gamma^{\prime}$ phase particles separated by the $\gamma$ phase matrix channels were noticed. Within the interdendritic areas, the occurrence of the $\gamma-\gamma^{\prime}$ eutectic system as well as a large number of carbides with the Chinese-script morphology, as in case of blade No. 1, were found. The average size of the $\gamma^{\prime}$ phase particles within the dendritic areas is $0.14 \pm 0.39 \mu \mathrm{m}^{2}$, however, the $\gamma^{\prime}$ phase surface fraction at the level of $58 \%$ was established. In the dendritic areas in the middle of the blade length, the highly developed and connected to each other $\gamma$ ' phase particles, separated by the thickened $\gamma$ phase matrix channels, were noticed, Fig. 5a. The microstructure changes of this type are characteristic of longterm exposure to high temperature. The $\gamma-\gamma^{\prime}$ eutectic system as well as many carbides were observed in the inter-dendritic area, Fig. 5b.

Within the cross section dendritic areas by the blade tip, very small ordered cuboidal $\gamma^{\prime}$ phase particles separated by the $\gamma$ phase matrix channels as well as small

compare the microstructure changes along the blade length. Within the longitudinal section studies, any microstructure changes along the blade length and any changes related to the longitudinal specimen were observed.

\subsection{Blade No. 2}

The microstructure analysis of blade No. 2 was conducted at the cross-sections (at the locking, in the middle of the length, and at the
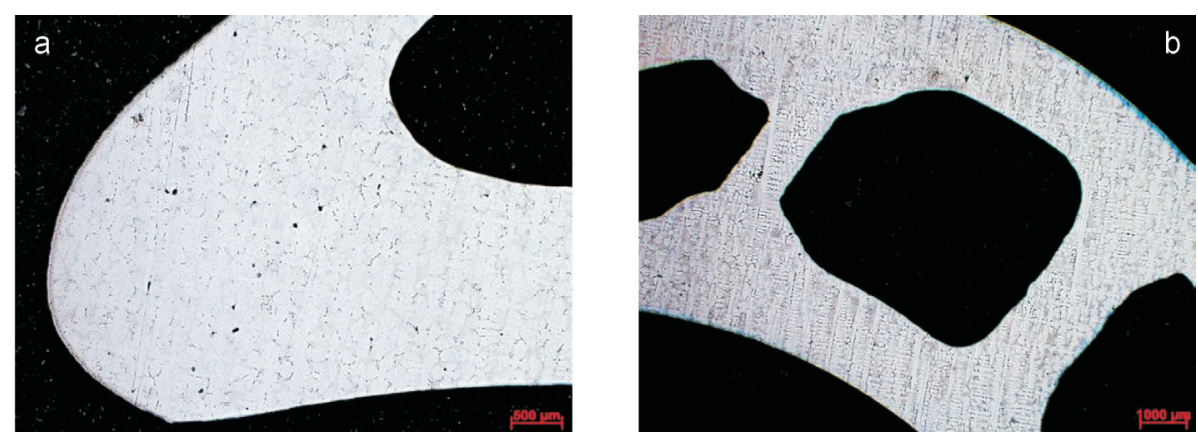

Fig. 4. The microstructure of blade No. 2: a) cross-section at the locking, dendritic structure, b) crosssection in the middle of the turbine blade leaf length, deviation from correct orientation of the crystallization direction, LM 

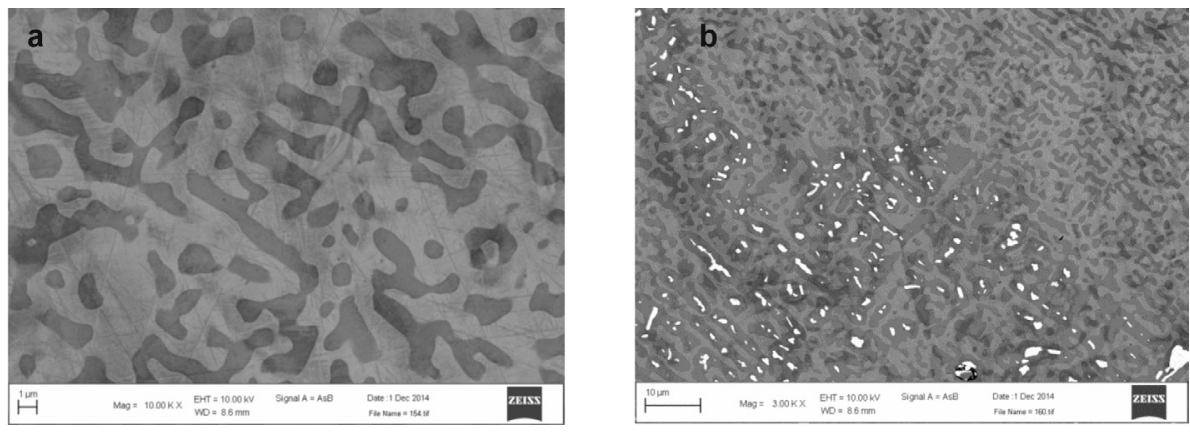

Fig. 5. The microstructure of blade No. 2: a) cross-section in the middle of the blade length, the developed and connected with each other $\gamma^{\prime}$ phase particles separated by the thickened $\gamma$ phase matrix channels, b) inter-dendritic area, $\gamma-\gamma$ ' eutectic system, carbide particles, SEM
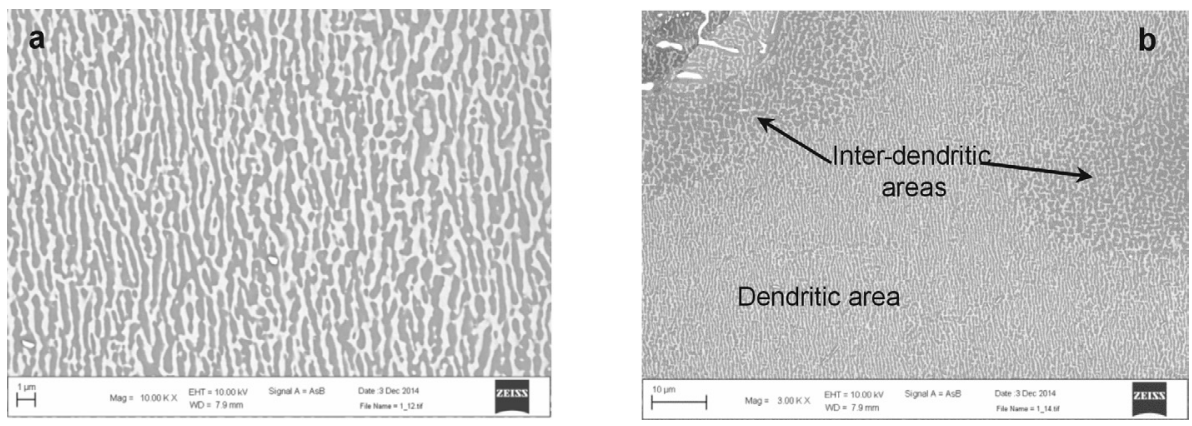

Fig. 6. The microstructure of blade No. 2, the upper longitudinal section: a) dendritic area, visible rafting phenomenon, b) dendritic and inter-dendritic area, SEM

carbides particles were noticed. A lot of carbides were observed within the inter-dendritic areas.

Longitudinal specimen were cut along the blade axis at a distance of about $6 \mathrm{~mm}$ from the leading edge dividing the blade into two parts - bottom one (including the area from the blade locking to a half of the turbine blade leaf height) and upper one (including the area from a half of the turbine blade leaf to the blade tip). Within the bottom longitudinal section dendritic areas, uniform acute $\gamma^{\prime}$ phase particles separated by the $\gamma$ phase matrix channels were noticed. In addition, the numerous carbides, which are characterised by the Chinesescript morphology, were observed within the inter-dendritic areas of this section. However, in the lower longitudinal blade section, any significant changes in the microstructure along the length of the entire section within individual areas were observed among each other.

The microstructure changes typical of the high-temperature creep process $-\gamma^{\prime}$ phase directional growth (the so-called rafting [17, 18]) at the uniaxial stress state, were noticed in the upper part of the longitudinal section of blade No. 2, Fig. 6a and b. The conducted research showed that the rafting phenomenon occurred only within the area, where the examined blade had the thinnest walls. The $\gamma^{\prime}$ phase particles orientation after a

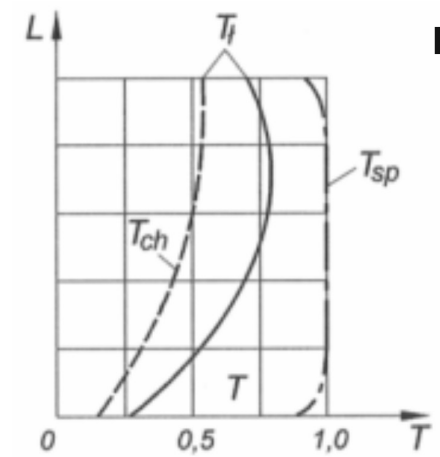

the $\gamma^{\prime}$ phase directional growth process shows the presence of the uniaxial tensile stress state related to the longitudinal blade axis within the examined area. In the inter-dendritic area, the $\gamma^{\prime}$ phase directional growth phenomenon was not observed because the initial microstructure within the inter-dendritic areas did not have the proper structuring to effect the necessary $\gamma^{\prime}$ phase directional growth, Fig. $6 \mathrm{~b}$.

\section{Conclusions}

The super alloys used to operate at a temperature above the limit temperature $\mathrm{T}_{\mathrm{g}}$ are called the heatresistant ones. The $T_{g}$ temperature for a given material is determined by the intersection point of the Re yield strength minimum value and the $\mathrm{R}_{\mathrm{Z}} / \mathrm{t} / \mathrm{T}$ creep-rupture strength. The maximum exhaust gas temperature before the considered gas turbine is $1536 \mathrm{~K}$ [11], and its distribution along the length of the turbine blade leaf is uneven (Fig. 7a).

The usefulness criterion of the given material as a heatresistant plastic can include the dependence of the stress value ratio to the Young's modulus $\sigma / \mathrm{E}$, i.e. the so-called standardised stress of homological temperature $\mathrm{T} / \mathrm{T}_{\mathrm{t}}$ characteristic of deformation mechanisms of a given material. Along with an increase in the blade operating temperature above the norm and within a specified time of its impact, a significant decrease in the $\mathrm{R}_{0.2}$ and $\mathrm{R}_{\mathrm{m}}$ strength properties occurs. Therefore, mechanical properties, especially the long-term creep-rupture strength, decrease $[1,14]$. The factor contributing to creep constituted the front turbine blade leaf construction, which influenced the increased normal stress $\sigma$ in relation to the blade without a plate (Fig. $7 \mathrm{~b}$ ). b

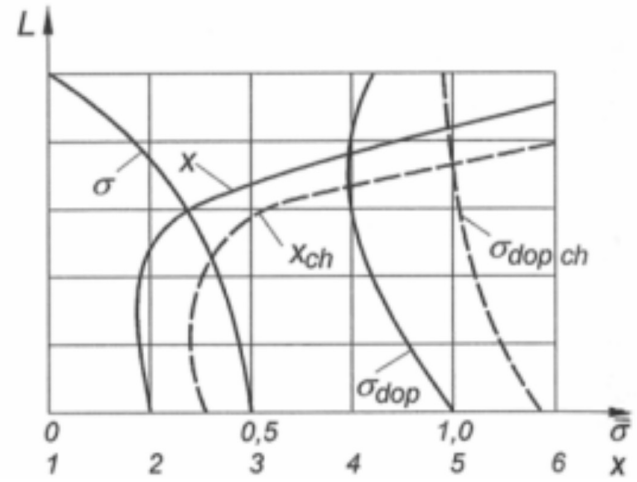

Fig. 7. The distribution of selected parameters along the $L$ turbine blade leaf of the turbine rotor: a) $T_{s p}$ exhaust gas temperature, $\mathrm{T}$ uncooled blade temperature and $\mathrm{T}$ cooled blade temperature, $\mathrm{b}$ ) normal stress in the turbine blade leaf without a plate $\sigma$ and with a plate $\sigma_{\mathrm{p}}$ at its tip, allowable stress $\sigma_{\text {dop }}$ and corresponding $\mathrm{x}$ and $\mathrm{x}_{\mathrm{p}}$ safety coefficients [11] 
The blade material's thermal expansion significantly affects the reduction of the turbine rotor tip clearance. Consequently, it results in rubbing of the blade front against the turbine body, which causes additional heating of the turbine blade leaf material and adverse effects on the super alloy microstructure. The changes typical of the high temperature creep process ( $\gamma^{\prime}$ phase directional growth) at the uniaxial stress state were observed only in case of the longitudinal section of the upper part of blade No. 2.

At the point, in which the blade has the thinnest walls of the section, which can affect the local increase of maximum temperature and stress. The $\gamma^{\prime}$ phase particles orientation after the $\gamma^{\prime}$ phase directional growth process shows the presence of the uniaxial tensile stress state related to the longitudinal blade axis within the examined area.

\section{Bibliography}

[1] Błachnio J. Analysis of causes of decohesion of a gas turbine blade made of EI-867WD alloy. Aircraft Engineering and Aerospace Technology: An International Journal. Vol. 83, No 1, 2011, p.14-20.

[2] Błachnio J. Analysis of technical condition assessment of gas turbine blades with non-destructive methods. Acta Mechanica et Automatica, vol. 7, no. 4, 2013, p. 203-208.

[3] Błachnio J. Capabilities to assess health/maintenance status of gas turbine blades with non-destructive methods. Polish Maritime Research, Vol. 21, No. 4 (84), 2014, p.41-47.

[4] Błachnio J., Spychała J., Pawlak W., Zasada D. The attempt to assess the technical condition of a gas turbine blade when information on its operating condition is limited. Journal of KONBiN 2(30) 2014, p. 75-86.

[5] Błachnio J., Kułaszka A., Zasada D. Degradation of the gas turbine blade coating and its influence on the microstructure state of the superalloy. Journal of KONES, Vol. 22, No. 2, 2015, p. 17-24.

[6] Dubiel B. Zmiany mikrostruktury podczas pełzania monokrystalicznych nadstopów niklu. Rozprawy, Monografie 235, Wydawnictwo Akademii Górniczo-Hutniczej, Kraków 2011.

[7] Góral M. et al. Diffusion sluminide coatings for TiAl intermetallic turbine blades. Intermetallics 19, 2011, p. 744-747.

[8] Hejwowski T. Nowoczesne powłoki nakładane cieplnie odporne na zużycie ścierne i erozyjne, Politechnika Lubelska, Lublin 2013.

[9] Kułaszka A., Błachnio J., Zasada D., Jóźwik P. The assessment of changes in the microstructure of a gas turbine blade with a non-destructive thermographic method. Journal of KONES, vol. 19, No 2, 2012, p. 271-281.

[10] Kułaszka A., Giewoń J. Protokoły z badań. Instytut Techniczny Wojsk Lotniczych, Warszawa 2014-2015.

Prof. Józef Błachnio, DSc, DEng. - researcher at the Air Force Institute of Technology, Warszawa. e-mail: jozef.blachnio@itwl.pl

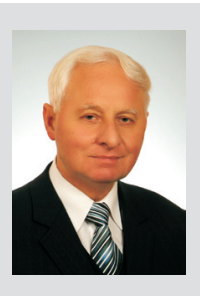

Artur Kułaszka - Air Force Institute of Technology, Warszawa.

e-mail: artur.kulaszka@itwl.pl
[11] Lotnicze silniki turbinowe, cz.1. Pod red. S. Szczecińskiego. Wydawnictwo Instytutu Lotnictwa, Warszawa 2010.

[12] Moskal G. Mikrostruktura i właściwości natryskiwanych plazmowo powłokowych barier cieplnych na bazie cyrkonianu gadolinu, Wydawnictwo Politechniki Śląskiej, Gliwice 2012.

[13] Nowak G. Optymalizacja kanałów wewnętrznego chłodzenia łopatek turbiny gazowej. Wydawnictwo Politechniki Śląskiej, Gliwice 2011.

[14] Sieniawski J. Kryteria i sposoby oceny materiałów na elementy lotniczych silników turbinowych, Oficyna Wydawnicza Politechniki Rzeszowskiej, Rzeszów 1995.

[15] Swadźba L. et al. Characterization of microstructure and properties of TBC systems with gradient of chemical composition and porosity, Archives of Metallurgy and Materials 53, 2008, p. 945-954.

[16] Szczepanik R., Błachnio J., Swadźba L. Opracowanie technologii nanoszenia powłok ochronnych TBC. Raport Instytutu Technicznego Wojsk Lotniczych, Warszawa 2001.

[17] Ziętara M., Cetel A., Czyrska-Filemonowicz A. Measurements of microstructure parameters In single-crystals nickel-base superalloy, Inżynieria Materiałowa 4(2008) p. 188-191.

[18] Ziętara M. Microstructure stability of second and fourth generation single crystal nickel-base superalloys during high temperature creep deformation, doctoral dissertation, Krakow: AGH University of Science and Technology, 2011.

[19] Yu Z., Liu L., Zhao X., Zhang W., Zhang J., Fu H. Effect of solidification rate on MC-type carbide morphology in single crystal Ni-base superalloy AM3, Transactions of Nonferrous Metals Society of China, vol. 20, no 10, 2010, p. 18351840.

Maciej Ziętara, DEng. - doctor in the Faculty of Metals Engineering and Industrial Computer Science at AGH University of Science and Technology. e-mail: zietara@agh.edu.pl

Prof. Aleksandra Czyrska-Filemonowicz, DSc, DEng. - professor in the Faculty of Metals Engineering and Industrial Computer Science at AGH University of Science and Technology.

e-mail: czyrska@agh.edu.pl
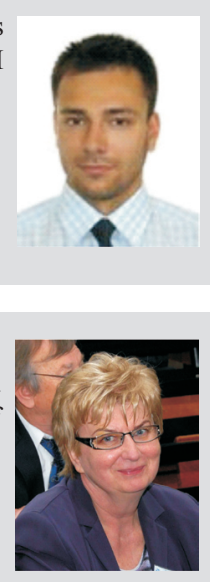